\title{
Analiza wpływu utrzymania i zmian ocen ratingowych na wysokość spreadu kredytowego na przykładzie polskiego rynku obligacji przedsiębiorstw w latach 2010-2017
}

\section{Streszczenie}

Celem artykułu jest określenie wpływu utrzymania i zmian ratingów kredytowych formułowanych przez agencję ratingową Moody's na wysokość spreadu kredytowego na polskim rynku długu przedsiębiorstw w latach 2010-2017. Podstawowym powodem podejmowanych działań jest próba oceny, czy polski rynek długu jest efektywny w sensie informacyjnym w odniesieniu do wiadomości rynkowych, takich jak podniesienie, utrzymanie lub obniżenie ratingu. Wykorzystywana metodyka opiera się na standardowej procedurze analizy zdarzeń. Wyniki przeprowadzonych badań nie są jednoznaczne, gdyż z jednej strony wskazują na poprawną reakcję wysokości spreadu kredytowego na zmiany ocen ratingowych, $\mathrm{z}$ drugiej zaś otrzymane rezultaty nie znajdują potwierdzenia $\mathrm{w}$ testach istotności statystycznej.

Słowa kluczowe: spread kredytowy, agencje ratingowe, efektywność rynku obligacji, Catalyst.

Klasyfikacja JEL: G01, G14, G29. 


\section{Wprowadzenie}

Za autora najczęściej przytaczanej definicji hipotezy efektywności informacyjnej rynku uznaje się E.F. Famę (1970). Według niego rynek jest efektywny informacyjnie wtedy, gdy ceny aktywów na nim notowanych odzwierciedlają wszystkie dostępne wiadomości oraz dostarczają inwestorom prawidłowych sygnałów do podejmowania decyzji lokacyjnych. Pomimo że hipotezą efektywności informacyjnej posługiwano się głównie w odniesieniu do rynku akcji, to wydaje się, że tę koncepcję można odnieść również do analizy sposobu funkcjonowania rynku obligacji. W tym przypadku przedmiotem zainteresowania należy uczynić to, w jaki sposób zmieniają się różnice pomiędzy dochodowością dłużnych papierów wartościowych przedsiębiorstw a rentownością obligacji skarbowych na obniżenie, utrzymanie lub podwyższenie ratingu emitenta. Jeżeli formułowanym (upublicznianym) ocenom towarzyszą odpowiednio wzrost, brak zmian i spadek spreadu kredytowego, przy czym w pierwszym i ostatnim przypadku rejestrowane zmiany mają charakter natychmiastowych dostosowań, to rynek obligacji korporacyjnych należy uznać za efektywny w odniesieniu do analizowanego zbioru informacji. Każda inna reakcja w postaci zmiany spreadu kredytowego na nowe wiadomości może być przejawem nieefektywności rynku obligacji korporacyjnych. Warto zauważyć, że w takim przypadku pojęcie efektywności rynku obligacji w sensie informacyjnym jest najbardziej zbliżone do hipotezy umiarkowanej efektywności. Przedmiotem zainteresowania czyni się bowiem reakcję inwestorów na napływ nowych informacji mających znaczenie dla notowań instrumentów finansowych.

Punktem wyjścia analizy przeprowadzanej na potrzeby niniejszego opracowania są trzy badania. Pierwsze z nich zostało wykonane przez M.E. Blume'a, F. Lima i A.C. MacKinlaya (1998) i dotyczyło analizy porównawczej ratingów przyznawanych w latach 70., 80. i 90. XX w. spółkom charakteryzującym się określonymi wskaźnikami księgowymi. Wyniki otrzymane na podstawie próby złożonej z firm amerykańskich potwierdziły, że wraz z upływem czasu agencje ratingowe wykazywały skłonność do przyznawania przeciętnie coraz gorszych ocen wiarygodności kredytowej poszczególnym podmiotom. Autorzy badania sformułowali dwa możliwe sposoby wytłumaczenia tego zjawiska. Po pierwsze, metodyka ocen wiarygodności kredytowej była cały czas udoskonalana, a podejście agencji ratingowych stawało się coraz bardziej restrykcyjne. Takie wyjaśnienie tendencji do przyznawania coraz gorszych ratingów wydaje się nie do końca uprawnione $\mathrm{w}$ kontekście zmiany modelu biznesowego funkcjonowania samych agencji. Po drugie, zaobserwowaną prawidłowość można wyjaśnić zmianą sposobu interpretacji wskaźników giełdowych przez grono uczestników rynku finansowego. W konsekwencji kryteria przyporządkowania spółek do grup o okre- 
Ślonym prawdopodobieństwie ogłoszenia bankructwa nie pokrywają się z kryteriami przyznawania konkretnych ratingów. Warto jednocześnie zauważyć, że zaproponowane przyczyny skłonności agencji ratingowych do przyznawania coraz gorszych ratingów są traktowane przez autorów bardziej jako przypuszczenia niż ostatecznie potwierdzone dowody.

Drugie badanie, które przeprowadzili R.L. Geske i G. Delianedis (1998), dotyczy zarówno udziałowych, jak i dłużnych papierów wartościowych emitowanych przez spółki amerykańskie w latach 1988-1999. Na podstawie danych historycznych autorzy opracowali dwa modele bazujące na wielkościach wskaźnikowych, które pozwalają lepiej oszacować prawdopodobieństwa podwyższenia lub obniżenia ratingów niż agencja Standard \& Poor's. W ramach wniosków z tego badania na szczególną uwagę zasługują dwa spostrzeżenia. Po pierwsze, istnieje możliwość przewidzenia zmiany oceny wiarygodności kredytowej oraz niewypłacalności podmiotu średnio na jeden miesiąc przed ujawnieniem tego faktu przez jedną z największych agencji ratingowych. Innymi słowy, odpowiednia interpretacja danych rynkowych daje możliwość antycypacji wydarzeń. Warto przy tym zauważyć, że opracowane modele sprawdzają się zarówno, jeśli chodzi o podmioty (emisje) o wysokim, jak i o niskim ratingu kredytowym. Po drugie, komunikaty agencji ratingowej Standard \& Poor's są opóźnione i nie mają większej wartości informacyjnej dla uczestników rynku. Słuszność takiego poglądu jest źródłem twierdzenia o tzw. lepkości ratingów kredytowych (rating stickiness).

Trzecie badanie dotyczy relacji pomiędzy stopami zwrotu w okresie do wykupu (yield to maturity) a ocenami wiarygodności kredytowej przyznawanymi przez agencje ratingowe. Jak dowodził E.I. Altman (1989), na podstawie danych dotyczących rynku amerykańskiego w latach 1973-1987 można było zaobserwować odwrotną zależność pomiędzy wysokością skali ratingowej a stopą zwrotu w okresie do wykupu (jeśli chodzi o obligacje przedsiębiorstw). Należy jednak zwrócić uwagę, że zależność taka istnieje jedynie dla wielkości uśrednionych w ramach poszczególnych kategorii ratingowych.

Powyższe badania podają w wątpliwość efektywność informacyjną rynku obligacji korporacyjnych. W celu dokładniejszej analizy szybkości oraz dokładności dostosowań cenowych do ogłoszeń informacji dotyczących utrzymania, podwyższenia oraz obniżenia ratingu kredytowego przeprowadzane są badania zarówno literaturowe, jak i empiryczne.

Celem opracowania jest analiza efektywności informacyjnej polskiego rynku obligacji korporacyjnych. Przedmiotem badania jest 31 serii dłużnych papierów wartościowych, które w okresie od początku stycznia 2010 r. do końca grudnia 2017 r. były przedmiotem obrotu w ASO w ramach Catalyst prowadzonym przez BondSpot SA. Próba badawcza obejmuje dłużne instrumenty finansowe, w odniesieniu do których agencja Moody's podjęła decyzję o podwyższeniu, 
utrzymywaniu na takim samym poziomie lub obniżeniu ratingu, przy czym bez znaczenia pozostają kwestie związane $\mathrm{z}$ istnieniem (lub nie) zabezpieczenia rozpatrywanych walorów, charakterem emitenta (podmiot finansowy lub niefinansowy) oraz szczegółowymi parametrami emisji. W artykule podjęto próbę określenia wpływu utrzymania, podwyższenia lub obniżenia ocen ratingowych przez agencję Moody's na szybkość dostosowań oraz wysokość spreadu kredytowego na polskim rynku obligacji przedsiębiorstw.

\section{Wpływ agencji ratingowych na ceny obligacji i wysokość spreadów kredytowych w literaturze i badaniach naukowych}

W literaturze przedmiotu istnieją dwa nurty badań związanych z wpływem agencji ratingowych na efektywność informacyjną rynku dłużnych papierów wartościowych. Pierwszy z nich dotyczy analizy wpływu ratingów na ceny rynkowe obligacji, drugi natomiast związany jest $\mathrm{z}$ analizą znaczenia ocen wiarygodności podmiotów na wysokość spreadów kredytowych emitowanych przez te podmioty obligacji korporacyjnych.

Jednymi z pierwszych autorów podejmujących problematykę zależności pomiędzy dochodowością obligacji a ratingami kredytowymi byli P. Liu i A.V. Thakor (1984). Wyszli oni z założenia, że stopy zwrotu w okresie do wykupu powinny być bardziej powiązane z ratingami i mniej z czynnikami o charakterze fundamentalnym. Ratingi kredytowe konstruowane są bowiem zarówno na podstawie informacji fundamentalnych, które w większości są publicznie dostępne, jak i wiadomości prywatnych, których pozyskanie wymaga długotrwałych poszukiwań i czasochłonnego przetwarzania danych. W takiej sytuacji odpłatne sporządzanie ratingów na zlecenie emitentów obligacji należałoby traktować jako chęć odróżnienia emisji własnych papierów wartościowych o charakterze dłużnym od emisji innych podmiotów. Innymi słowy, zamówienie ratingu motywowane jest chęcią uniknięcia przyznania uśrednionej oceny ratingowej (average quality pricing) w rozumieniu G.A. Akerlofa (1970). Otrzymane wyniki wydają się potwierdzać początkowe przypuszczenia. Czynniki fundamentalne w połączeniu z oceną ratingową istotnie determinują poziomy dochodowości obligacji. Jednocześnie nie można odrzucić hipotezy o istnieniu pojedynczego czynnika, tj. ratingu, jako istotnej determinanty rentowności obligacji.

Do nieco odmiennych wniosków doszli L.H. Ederington, J.B. Yawitz i B.E. Roberts (1987). Na podstawie ocen wiarygodności kredytowej Moody's i Standard \& Poor's dotyczących przedsiębiorstw amerykańskich sformułowali oni wniosek, zgodnie z którym uczestnicy rynku większą wagę przywiązują do danych finansowych emitentów (w szczególności ostatnio opublikowanych) niż do 
ocen agencji ratingowych. Należy przy tym zaznaczyć, że zależności pomiędzy czynnikami o charakterze księgowym a rentownościami poszczególnych obligacji nie są proste do rozpoznania nawet w ramach portfela spółek o określonej ocenie wiarygodności kredytowej. Pomimo to najlepszym sposobem przewidywania rentowności dłużnych papierów wartościowych jest łączne analizowanie danych finansowych i ratingów sporządzanych przez podmioty zewnętrzne.

Część autorów, np. S. Katz (1974), R.R. West (1973), C. Kao i C. Wu (1990), D. Kliger i O. Sarig (2000), podjęła problematykę reakcji rynku na napływ informacji dotyczących zmiany lub utrzymania ratingu w przypadku emitentów dłużnych papierów wartościowych. Punktem wyjścia analizy przeprowadzonej przez D. Kligera i O. Sariga (2000) było pytanie dotyczące przydatności ratingów kredytowych. Jako tezy zostały sformułowane dwie prawidłowości. Po pierwsze, muszą istnieć powody, dla których emitenci papierów wartościowych decydują się na zapłatę za przeprowadzenie oceny wiarygodności kredytowej przez wyspecjalizowane podmioty zewnętrze, jakimi są agencje ratingowe. Po drugie, decyzje dotyczące kupna raportów agencji ratingowych przez inwestorów muszą być w jakiś sposób umotywowane. D. Kliger i O. Sarig (2000) doszli do wniosku, że tym, co skłania obie kategorie podmiotów do korzystania z ratingów kredytowych, jest informacja wewnętrzna w nich zawarta. Instytucje zajmujące się oceną wiarygodności kredytowej potrafiły dokonać oceny ratingowej poszczególnych podmiotów bez dostępu do poufnych informacji swoich klientów (korzyść dla emitentów dłużnych papierów wartościowych). Jednocześnie agencje ratingowe były w stanie odpowiednio zinterpretować upublicznione dane finansowe lub też w taki sposób przetworzyć informacje pochodzące od emitenta, że stanowiły one wartość dodaną z punktu widzenia inwestorów angażujących posiadane kapitały na rynku długu (korzyść dla inwestorów).

Analizując reakcje rynku jako całości na zmianę ratingów przyznawanych przez Moody's, D. Kliger i O. Sarig (2000) stwierdzili, że ceny obligacji zmieniały się w zależności od zmian ratingów przyznawanych dłużnym papierom wartościowym. Ma to oczywiście swoje konsekwencje w zmianie rentowności i spreadów kredytowych.

Zagadnienia poruszone przez D. Kligera i O. Sariga (2000) zostały podjęte również przez G. Hite’a i A. Wargę (1997). Według tych autorów na podstawie danych dotyczących emisji obligacji w Stanach Zjednoczonych w latach 1985-1995 można stwierdzić, że największy spadek rentowności obligacji następował w okresie od sześciu miesięcy do czterech tygodni przed podwyższeniem ratingu, ale tylko w przypadku emisji, których ocena wzrastała z poziomu śmieciowego do inwestycyjnego. W przypadku podwyższenia ratingów w ramach kategorii obligacji śmieciowych albo inwestycyjnych spadek rentowności należało uznać za znikomy. Analogiczne zjawisko występowało w przypadku obniżenia ratingów 
przyznawanych emisjom dłużnych papierów wartościowych. W przypadku, gdy ocena ratingowa obligacji zmieniała się do poziomu śmieciowego, reakcja cenowa była najsilniejsza.

Podsumowując, można stwierdzić, że istnieje wiele podmiotów korzystających z ratingów kredytowych. Dla inwestorów indywidualnych ogłoszenia dotyczące utrzymania lub zmiany ocen wiarygodności kredytowej emitentów mogą stanowić sygnały świadczące o asymetrii informacyjnej, jaka pojawia się na rynku długu. Dla inwestorów instytucjonalnych rozróżnienie ratingów inwestycyjnych i nieinwestycyjnych jest istotne przy konstruowaniu portfeli lokat (tym bardziej, im bardziej globalny charakter ma dywersyfikacja). Dostarczyciele kapitałów, m.in. banki, również korzystają z ratingów kredytowych w celu np. ustalenia stóp procentowych kredytów i kontroli zaangażowania kapitałowego w podmiotach zewnętrznych. W związku z tym ogłoszenia o zmianach lub utrzymaniu ratingów dokonywane przez agencje ratingowe mają znaczący wpływ na rynek dłużnych papierów wartościowych.

Istnieje wiele badań empirycznych dotyczących reakcji rynku długu na decyzje podmiotów dokonujących ocen wiarygodności kredytowych. Warto wspomnieć chociażby o analizach H. Xia (2013), P. Joriona i G. Zhanga (2007), K.N. Danielsa i M.S. Jensena (2005) czy L. Nordena i M. Webera (2004). Otrzymane przez nich wyniki nie są jednak jednoznaczne.

Niektórzy autorzy, jak np. J. Jewell i M. Livingston (1999), wskazują na to, że ratingi dłużnych papierów wartościowych zawierają informacje istotne dla uczestników rynku. Inni, jak np. F. Partnoy (2001), R.W. Holthausen i R.W. Leftwich (1986), twierdzą, że ratingi kredytowe charakteryzują się niewielką zawartością informacyjną, gdyż ceny obligacji dostosowują się do zmieniającej się kondycji finansowej emitentów na długo przed ogłoszeniem komunikatu o zmianie oceny wiarygodności kredytowej. Podobny pogląd prezentują E.I. Altman i A. Saunders (2001), którzy zasugerowali, że agencje ratingowe w swoich działaniach były opieszałe i nieelastyczne. Podali oni tym samym pod wątpliwość zdolność agencji ratingowych do przewidywania przyszłej sytuacji rynkowej.

Brak zgody badaczy zaobserwować można również w kwestii wpływu ogłoszeń dotyczących podwyższenia lub obniżenia ocen ratingowych na rynek długu. Niektóre analizy wykazują, że obniżenia ratingów są w dużym stopniu przewidywalne i silniej determinują kursy rynkowe obligacji niż ogłoszenia dotyczące podwyższenia formułowanych ocen. Inni autorzy odnotowują natomiast znaczące efekty cenowe w przypadku obu rodzajów ogłoszeń. W konsekwencji trudno jest stwierdzić, czy agencje ratingowe są w stanie generować cenne informacje rynkowe poprzez ogłoszenia zmian ocen ratingowych, czy też nie.

Innym aspektem funkcjonowania agencji ratingowych, na który zwracają uwagę m.in. J.E. Stiglitz i A. Weiss (1981), jest rola tego typu instytucji w funkcjo- 
nowaniu systemu finansowego jako całości. Sprowadza się ona do redukcji asymetrii informacji występującej pomiędzy pożyczkodawcami a pożyczkobiorcami. Podmioty te przyczyniają się również do eliminacji przejawów nieefektywności funkcjonowania rynku finansowego oraz sprzyjają podejmowaniu bardziej racjonalnych decyzji przez inwestorów.

Poza redukcją asymetrii informacji istnieje wiele innych korzyści wynikających z funkcjonowania agencji ratingowych. Jak zauważają R.T.S. Ramakrishnan i A.V. Thakor (1984), agencje ratingowe, gromadząc oraz przetwarzając informacje, obniżają koszt pozyskania kapitału przez przedsiębiorstwa. Ponadto, jak wykazuje D.T. Beers (2010), agencje ratingowe poprawiają atrakcyjność lokalnego rynku kapitałowego, zwiększają zagraniczne inwestycje bezpośrednie, ułatwiają dostęp sektora prywatnego do globalnych rynków kapitałowych oraz poprawiają transparentność sektora publicznego.

Ze względu na rolę, jaką odgrywają agencje ratingowe, w szczególności na rynkach instrumentów dłużnych oraz produktów strukturyzowanych, ewentualne błędy i pomyłki podmiotów dokonujących ocen wiarygodności kredytowej mogą mieć poważne konsekwencje dla funkcjonowania przedsiębiorstw, poszczególnych rynków oraz samych państw. F. Partnoy (2006) określa wpływ Moody's i Standard \& Poor's na działanie rynku finansowego jako „niebezpieczny”. E. Benmelech i J. Dlugosz (2010), V. Skreta i L. Veldkamp (2009) oraz A. Ashcraft, P. Goldsmith-Pinkham i J. Vickery (2010) argumentują, że agencje ratingowe są wręcz częściowo odpowiedzialne za wywołanie kryzysu finansowego z 2008 r. Inni autorzy, np. R.A. De Santis (2012), dowodzą natomiast, że agencje ratingowe przyczyniły się do pogorszenia sytuacji finansowej takich państw, jak Grecja, Irlandia, Portugalia, Włochy czy Hiszpania.

Warto zauważyć, że krytyka funkcjonowania agencji ratingowych przed upadkiem banku Lehman Brothers 15 września 2008 r. sprowadzała się do stwierdzenia, iż podmioty te mogły wywoływać wzrost niestabilności i zmienności rynków finansowych.

Jak zauważają m.in. H. Reisen i J. von Maltzan (1999) oraz G. Larrain (Larrain, Reisen i Maltzan 1997), trzy największe agencje ratingowe, podnosząc i obniżając oceny wiarygodności kredytowej, mają zdolność do wpływania na rentowność dłużnych papierów wartościowych zarówno poszczególnych przedsiębiorstw, jak i państw. R.I. McKinnon i H. Pill (1996) stwierdzają dodatkowo, że antycypując optymistyczne lub pesymistyczne zachowania inwestorów na rynku finansowym, podmioty te mogą sprzyjać wyrównywaniu górnych i dolnych punktów zwrotnych cykli koniunkturalnych. Niestety potencjał ten nie jest wykorzystywany przez instytucje dokonujące ocen wiarygodności kredytowej innych uczestników rynku. W rzeczywistości ich działanie, sprowadzające się do podniesienia lub obniżenia ratingu, ma miejsce po pojawieniu się i zdyskontowaniu pozytywnych lub nega- 
tywnych informacji przez rynek. Ze względu na opóźnione działanie agencji ratingowych formułowanie ocen wiarygodności w odniesieniu do poszczególnych podmiotów należy uznać za wzmacniające wahania rynku finansowego. Poprawa ratingu danego podmiotu rozbudza pozytywne oczekiwania inwestorów i stymuluje napływ kapitału, co powoduje obniżenie spreadu pomiędzy rentownością obligacji o danym ratingu a dochodowością rządowych papierów wartościowych (yield spread). Pogorszenie ratingu wywołuje natomiast odpływ kapitału, który jest źródłem zwiększenia różnicy pomiędzy dochodowościami obligacji o danym ratingu i obligacji rządowych. W konsekwencji wzrasta zmienność rynku długu i jego niestabilność.

Z powyższymi opiniami wydają się zgadzać m.in. G. Kaminsky i S.L. Schmuckler (2002), którzy dowodzą, że agencje ratingowe mają skłonność do obniżania ratingów w okresie spowolnienia gospodarczego i ich podwyższania w okresie prosperity. Jeśli dodać do tego opóźnioną reakcję podmiotów dokonujących ocen wiarygodności kredytowej, to można łatwo zauważyć, że ich funkcjonowanie wywołuje nadreaktywność inwestorów i przyczynia się do wzrostu zarówno spreadu kredytowego, jak i zmienności rynku długu.

G. Loeffler (2005) zauważa ponadto, że źródłem opóźnionego działania agencji ratingowych jest ich skłonność do zmiany ratingu tylko wtedy, gdy istnieje niskie prawdopodobieństwo zmiany nowo przyznanej oceny wiarygodności kredytowej. W konsekwencji podwyższenie lub obniżenie ratingu następuje po zmianie ryzyka niewypłacalności emitenta dłużnych papierów wartościowych. Zwiększa to zmienność rynku i przyczynia się do jego niestabilności.

Po kryzysie finansowym z 2008 r. krytyka funkcjonowania agencji ratingowych dotyczyła przede wszystkim samego mechanizmu formułowania ocen wiarygodności kredytowej. Jak zauważają S. Lugo, A. Croce i R. Faff (2013), emitenci papierów wartościowych lub oceniane podmioty są skłonni zapłacić agencji ratingowej za dokonanie oceny wiarygodności kredytowej tylko wtedy, gdy otrzymana ocena jest dla nich satysfakcjonująca (rating shopping). W rezultacie agencje ratingowe wykazują skłonność do zawyżania przyznawanych ratingów, które określane są mianem „nadmuchiwanych” (inflated ratings). Tego typu model (issuer paid) stoi w opozycji do sposobu funkcjonowania rynku agencji ratingowych, na którym za ocenę wiarygodności kredytowej podmiotu lub określenie ,jakości” dłużnych papierów wartościowych płacą poszczególni inwestorzy. Według D. Bongaertsa (2014) taki model biznesowy funkcjonowania agencji ratingowych w mniejszym stopniu przyczynia się do zniekształcania formułowanych ocen wiarygodności kredytowej oraz „nadmuchiwania” ratingów.

Inne zjawisko, na które zwracają uwagę P. Bolton, X. Freixas i J. Shapiro (2012) oraz D.S. Scharfstein i J.C. Stein (1990), polega na celowym zawyżaniu formułowanych ocen wiarygodności kredytowej przez agencje ratingowe, co może być 
spowodowane ich „długoterminowym oportunizmem”. Ze względu na to, że ratingi określonych agencji ratingowych są „nadmuchiwane”, oceny formułowane przez inne podmioty również są systematycznie zawyżane. W rezultacie pojawia się zjawisko stadnego zachowania podmiotów w ramach tego segmentu rynku finansowego (herding) skutkujące zwiększeniem zmienności i niestabilności rynku długu.

\section{Badania empiryczne}

W celu rozpoznania, jak inwestorzy reagują na podwyższenie, utrzymanie bez zmian lub obniżenie ratingu dłużnych papierów wartościowych przedsiębiorstw, zaproponowano metodę badawczą opierającą się na analizie zdarzeń.

W pierwszym etapie wykonywanych badań ze strony internetowej www. moodys.com pozyskano dane dotyczące emisji dłużnych papierów wartościowych podmiotów, których ocena wiarygodności kredytowej została przeprowadzona przez agencję Moody's w okresie od początku stycznia 2010 r. do końca grudnia 2017 r. Próbą objętych zostało 31 serii dłużnych papierów wartościowych wyemitowanych przez spółki, w stosunku do których wydano ponad 130 decyzji ratingowych (rating actions) w całym okresie analizy. Warto zauważyć, że z próby wyeliminowano te decyzje agencji Moody's, które polegają na przyznawaniu i wycofywaniu ocen wiarygodności kredytowej. Związane jest to z tym, że przedmiotem analizy są wyłącznie decyzje, które skutkują podwyższeniem, utrzymywaniem na takim samym poziomie lub obniżaniem ratingu.

W ramach przyjętej metodologii badań obligacje nie są grupowane ze względu na szczegółowe parametry emisji. Oznacza to, że w próbie znajdują się zarówno obligacje niezabezpieczone, jak i zabezpieczone hipoteką lub innymi rodzajami aktywów. Warto jednocześnie zauważyć, że dłużne papiery wartościowe różnią się pomiędzy sobą zarówno jeśli chodzi o moment zapadalności oraz długość okresu pozostającego do wykupu, jak i wysokość ratingu.

Należy zaznaczyć, że analizowane dane uwzględniają informacje dotyczące instrumentów instytucji finansowych, przede wszystkim banków, pomimo że podmioty te różnią się specyfiką prowadzonej działalności od pozostałych przedsiębiorstw. Następnie oblicza się dzienne rentowności w okresie do wykupu dla wszystkich uwzględnionych instrumentów dłużnych (wyemitowanych przez oceniane przedsiębiorstwa), które były przedmiotem obrotu w ASO w ramach Catalyst prowadzonym przez BondSpot SA w dowolnym okresie pomiędzy początkiem stycznia 2010 r. a końcem grudnia 2017 r.

Otrzymane wielkości zestawiane są z dziennymi rentownościami dziesięcioletnich obligacji skarbowych. Różnice pomiędzy dwiema wielkościami definiują poziomy spreadu kredytowego, tj.: 


$$
c s_{c, t}=r_{c, t}-r_{s, t},
$$

gdzie:

$c s_{c, t}$ - różnica pomiędzy rentownością obligacji korporacyjnej $c$ a rentownością dziesięcioletniej obligacji skarbowej $s$ w okresie $t$,

$r_{c, t}$ - rentowność obligacji korporacyjnej $c$, okresie $t$,

$r_{s, t}$ - rentowność dziesięcioletniej obligacji skarbowej $s$ w okresie $t$.

Warto przy tym zauważyć, że przy obliczaniu spreadu kredytowego czynione jest pewne uproszczenie. Wynika ono z tego, że chcąc wyznaczyć spread kredytowy, należy przyjąć założenie dotyczące tego, co jest uznawane za stopę zwrotu wolną od ryzyka. W przypadku obligacji korporacyjnych zwykle zakłada się, że pojęcie to jest tożsame z rentownością obligacji skarbowych o podobnym terminie zapadalności. Według R. Geske i G. Delianedisa (2001) stwierdzenie takie nie jest jednak kompletne, gdyż przy wyznaczaniu spreadu kredytowego wymagane jest nie tylko podobieństwo terminów zapadalności skarbowych i korporacyjnych papierów wartościowych o charakterze dłużnym, ale także zgodność analizowanych instrumentów fỉnansowych pod względem sposobu naliczania i terminu wypłat płatności kuponowych. Jednoczesne spełnienie obu tych warunków w badanym okresie dla polskiego rynku długu jest trudne. Ponadto należy zauważyć, że większość obligacji korporacyjnych w okresie objętym analizą ma charakter długoterminowy, zaś rentowność dziesięcioletnich obligacji skarbowych często utożsamiana jest ze stopą zwrotu wolną od ryzyka (Boss i Scheicher 2002). Z tych powodów na potrzeby przeprowadzanego badania spread kredytowy obliczany jest jako różnica pomiędzy rentownościami obligacji korporacyjnych i dziesięcioletnich skarbowych papierów wartościowych.

W dalszym etapie podejmowanych działań przedmiotem zainteresowania uczyniono siedmio- (trzy dni przed zdarzeniem, dzień zdarzenia rynkowego i trzy dni po zdarzeniu) i jedenastodniowe okna czasowe (pięć dni przed zdarzeniem, dzień zdarzenia rynkowego i pięć dni po zdarzeniu), których środek wyznaczany jest przez zdarzenie polegające na utrzymaniu, podwyższeniu lub obniżeniu ratingu kredytowego.

Należy mieć jednak na uwadze, że przedmiotem analizy są wyłącznie informacje o podwyższeniu, obniżeniu lub utrzymaniu ratingu, nie zaś same zapowiedzi korekty lub pozostawienia bez zmian dotychczasowych ocen wiarygodności kredytowej. Ponadto w badaniu nie są uwzględniane zdarzenia takie jak wciągnięcie na listę obserwacyjną (watch list) czy ogłoszenie perspektyw ratingowych (rating outlook).

Warto również zauważyć, że trudno jest zdefiniować skończony zbiór determinant spreadu kredytowego. Fakt ten należy uznać za jeden z powodów pojawienia się tzw. zagadki spreadu kredytowego (credit spread puzzle) polegającej na braku 
możliwości uzasadnienia premii za ryzyko związane z inwestycjami w obligacje korporacyjne kompletną listą czynników, których istotność jest empirycznie potwierdzona.

Nie można również pominąć dowodów na to, że na wielu rynkach, w różnych okresach, poszczególne czynniki oraz ich kombinacje często nie pozwalają na wyjaśnienie w zadowalającym stopniu różnicy pomiędzy oprocentowaniem korporacyjnych i rządowych papierów wartościowych o charakterze dłużnym. Potwierdzają to m.in.: E.J. Elton, M.J. Gruber, D. Agrawal i C. Mann (2001), którzy argumentują, że w latach 1987-1996 w odniesieniu do obligacji amerykańskich emitowanych przez spółki przemysłowe za pomocą oczekiwanej upadłości i podatków nie można było wytłumaczyć aż 46,17\% zmian spreadu kredytowego obliczanego dla dziesięcioletnich dłużnych papierów wartościowych o ratingu A. Wydaje się, że podobnego zdania są P. Collin-Dufresn, R.S. Goldstein i S.J. Martin (2001). Na uwagę zasługuje spostrzeżenie, zgodnie z którym za najlepsze predyktory opracowanego modelu należy uznać zmienne, które nie opisują zachowania rynków akcji i obligacji. J. Driessen (2005) zwraca natomiast uwagę na premię za płynność, która może determinować wysokość spreadu kredytowego, ale jedynie w ograniczonym stopniu.

Biorąc pod uwagę powyższe spostrzeżenia, należy stwierdzić, że trudno jest wyjaśnić różnice powstające w oprocentowaniu obligacji korporacyjnych i skarbowych pojedynczymi czynnikami wybranymi z grona wcześniej wymienionych. Ponadto w przypadku niektórych wielkości (np. ryzyka płynności) istnieje problem związany ze sposobem ich pomiaru, co utrudnia określenie wpływu tego typu czynników na analizowaną zmienną.

Dodatkowo należy zauważyć, że decyzje o podwyższeniu lub obniżeniu stóp procentowych NBP w latach objętych badaniem, tj. 2010-2017, jedynie trzykrotnie były podejmowane w oknach czasowych uwzględnionych w badaniu. Wyklucza to możliwość istotnego wpływu polityki pieniężnej NBP na otrzymane wyniki. W konsekwencji w dalszej części opracowania pominięto wpływ zmian stóp procentowych na podwyższenie lub obniżenie spreadu kredytowego.

Następnie dla uwzględnionych interwałów sprawdzono zachowanie przeciętnych skumulowanych spreadów kredytowych, tj. $\operatorname{accs}_{t-k}$, wyznaczanych zgodnie z poniższym wzorem:

$$
\operatorname{accs}_{t-k}=\sum_{c=1}^{n} \frac{c c s_{c, t-k}}{n}
$$

gdzie:

$c c s_{t-k}$ - skumulowana wartość spreadu kredytowego w okresie od $t$ do $k$ $\left(c c s_{c, t-k}=\sum_{t=k}^{t} c s_{c, t}\right)$,

$n$ - liczebność próby. 
Na szczególną uwagę zasługuje to, że uśrednienie przeprowadzane jest na podstawie danych z różnych okresów. To, co łączy każdą z trzech rozpatrywanych grup obserwacji, to zmiana ratingu, tzn. podniesienie, obniżenie lub utrzymanie dotychczasowej oceny wiarygodności emitenta obligacji.

Ostatecznie w celu sprawdzenia, czy wartości przeciętnych skumulowanych spreadów kredytowych są istotne statystycznie, obliczane są statystyki $t$-Studenta jako ilorazy przeciętnych wartości skumulowanych spreadów kredytowych (z poszczególnych emisji obligacji) do odchyleń standardowych skumulowanych spreadów kredytowych obliczanych dla poszczególnych okresów:

$$
J=\frac{\operatorname{accs}_{t-k}}{\bar{\sigma}},
$$

gdzie:

$a c s_{t-k}$ - przeciętna wartość skumulowanego spreadu kredytowego,

$\bar{\sigma}$ - odchylenie standardowe spreadów kredytowych $\left(\bar{\sigma}=\sigma_{t} / \sqrt{n}\right)$.

Zmiany przeciętnych wartości spreadów kredytowych (w punktach procentowych) są zawarte w tabeli 1.

Tabela 1. Zmiany przeciętnych wartości spreadów kredytowych polskich obligacji korporacyjnych liczonych narastająco (w punktach procentowych) w okresie od początku stycznia 2010 r. do końca grudnia 2017 r.

\begin{tabular}{|c|c|c|c|}
\hline Okres & Obniżenie ratingu & Utrzymanie ratingu & Podwyższenie ratingu \\
\hline$(-3,+3)$ & 0,36 & $-0,08$ & $-0,72$ \\
& $(0,56)$ & $(-0,12)$ & $\left(-4,12^{\text {a }}\right)$ \\
\hline$(-5,+5)$ & 0,18 & $-0,06$ & $-0,31$ \\
& $(0,15)$ & $(-0,09)$ & $(-1,24)$ \\
\hline
\end{tabular}

(.) - statystyki $t$-Studenta; ${ }^{a}$ istotne statystycznie na poziomie $\alpha=0,05$.

Źródło: opracowanie własne.

Analizując otrzymane wyniki, nie można jednoznacznie stwierdzić, czy rynek polskich obligacji korporacyjnych jest efektywny w sensie informacyjnym. $\mathrm{Z}$ jednej strony można zaobserwować poprawną reakcję spreadu kredytowego na napływające wiadomości (w siedmiodniowych oknach czasowych w przypadku podwyższenia ratingu), $\mathrm{z}$ drugiej jednak strony rejestrowane zmiany w większości przypadków nie są istotne statystycznie. W konsekwencji nie można sformułować jednoznacznego wniosku dotyczącego szybkości i poprawności reakcji rynku na wydawane decyzje ratingowe.

Na poprawnie funkcjonującym rynku podniesienie ratingu emitenta obligacji prowadzi zwykle do spadku stopy zwrotu w okresie do wykupu. Jednocześnie średni poziom spreadu kredytowego obniża się. W przeprowadzonych badaniach, 
na skutek podwyższenia ratingu, wartość spreadu kredytowego rozumianego jako różnica pomiędzy dochodowością obligacji korporacyjnych a rentownością dziesięcioletnich rządowych papierów wartościowych liczona narastająco spadła w siedmiodniowym oknie czasowym przeciętnie o 0,72 p.p. Analizowana wielkość dla przedziału czasowego obejmującego pięć dni przed podwyższeniem ratingu, dzień zdarzenia oraz kolejne pięć dni po ogłoszeniu decyzji ratingowej obniżyła się o 0,31 p.p. Na uwagę zasługuje to, że tylko w pierwszym przypadku rejestrowana różnica jest istotna statystycznie.

Na zasadzie analogii można stwierdzić, że obniżenie ratingu powinno być przyczyną wzrostu spreadu kredytowego. W przypadku obligacji korporacyjnych, które zostały objęte badaniem, można było zaobserwować wzrost różnicy pomiędzy dochodowością dłużnych papierów wartościowych a rentownością walorów wyemitowanych przez rząd. Będąca przedmiotem zainteresowania wartość wzrosła o 0,36 p.p. dla siedmiodniowego okna czasowego i o 0,18 p.p. dla jedenastodniowego przedziału czasowego, którego środek wyznaczany był przez decyzję agencji ratingowej. Obydwie wartości nie są jednak istotne statystycznie.

Warto zauważyć, że utrzymaniu oceny wiarygodności kredytowej przez Moody’s towarzyszyło zwykle obniżenie wartości spreadu kredytowego, chociaż rejestrowane zmiany były niewielkie. Podobnie jak poprzednio, empirycznie rozpoznana zależność nie znalazła jednak potwierdzenia w testach statystycznych.

\section{Podsumowanie}

Trudno jest dokonać jednoznacznej oceny działalności agencji ratingowych. $\mathrm{Z}$ jednej strony są to podmioty, które dostarczają informacji inwestorom o ryzyku kredytowym poszczególnych emitentów oraz obniżają koszty pozyskania kapitału przez przedsiębiorstwa, z drugiej zaś przyczyniają się do wzrostu niestabilności i zmienności przede wszystkim na rynku długu.

Nie sposób pominąć wpływu agencji ratingowych na ceny obligacji korporacyjnych i wysokość przeciętnego spreadu kredytowego utożsamianego z różnicą pomiędzy średnią rentownością dłużnych papierów wartościowych emitowanych przez przedsiębiorstwa a dochodowością obligacji skarbowych. W literaturze brakuje jednoznacznych dowodów zarówno na istnienie, jak i na brak wpływu ogłoszeń o zmianie ocen wiarygodności kredytowej na wysokość różnicy w rentownościach ww. walorów. Pomimo to przeważa pogląd, że podwyższenie ratingu powinno skutkować obniżeniem spreadu kredytowego. Informacje o poprawie wiarygodności kredytowej przedsiębiorstw upubliczniane przez agencje ratingowe powinny być natomiast przyczyną zwyżki analizowanej kategorii ekonomicznej. 
Kwestią otwartą pozostaje to, czy agencje ratingowe ostatecznie poprawiają, czy pogarszają efektywność informacyjną rynku finansowego.

Wyniki badań przeprowadzonych dla polskiego rynku obligacji korporacyjnych w latach 2010-2017 nie pozwalają jednoznacznie stwierdzić, czy zmiany ratingu przedsiębiorstw znajdują odzwierciedlenie w zmianach spreadów kredytowych. Na podstawie przeprowadzonych analizy statystycznej nie można bowiem uznać obserwowanych dostosowań do napływających informacji za wystarczające. W konsekwencji sformułowanie wniosku dotyczącego istnienia lub braku efektywności informacyjnej rynku długu korporacyjnego w Polsce wymaga dalszych pogłębionych badań.

\section{Literatura}

Akerlof G.A. (1970), The Market for "Lemons": Qualitative Uncertainty and the Market Mechanism, „The Quarterly Journal of Economics”, vol. 84, nr 3, https://doi. org/10.2307/1879431.

Altman E.I. (1989), Measuring Corporate Bond Mortality and Performance, „The Journal of Finance", vol. 44, nr 4, https://doi.org/10.1111/j.1540-6261.1989.tb02630.x.

Altman E.I., Saunders A. (2001), An Analysis and Critique of the BIS Proposal on Capital Adequacy and Rating, ,Journal of Banking and Finance”, vol. 25, nr 1, https://doi. org/10.1016/s0378-4266(00)00116-3.

Ashcraft A., Goldsmith-Pinkham P., Vickery J. (2010), MBS Ratings and the Mortgage Credit Boom, Federal Reserve Bank of New York Staff Reports, nr 449, Federal Reserve Bank of New York, New York.

Beers D.T. (2010), The Future of Sovereign Credit Ratings, http://blogs.sciences-po.fr/ recherche-predictions/files/2010/12/the-future-of-sovereign-credit-ratings-SPs.pdf (data dostępu: czerwiec 2018).

Benmelech E., Dlugosz J. (2010), The Credit Rating Crisis, www.nber.org/chapters/ c11794.pdf (data dostępu: czerwiec 2018).

Blume M.E., Lim F., MacKinlay A.C. (1998), The Declining Credit Quality of U.S. Corporate Debt: Myth or Reality?, „The Journal of Finance”, vol. 53, nr 4, https://doi. org/10.1111/0022-1082.00057.

Bolton P., Freixas X., Shapiro J. (2012), The Credit Ratings Game, „The Journal of Finance", vol. 67, nr 1, https://doi.org/10.1111/j.1540-6261.2011.01708.x.

Bongaerts D. (2014), Alternatives for Issuer-paid Credit Rating Agencies, European Central Bank Working Paper Series, nr 1703, European Central Bank, Frankfurt am Main.

Boss M., Scheicher M. (2002), The Determinants of Credit Spread Changes in the Euro Area (w:) Market Functioning and Central Bank Policy, Bank for International Settlements, Basel.

Collin-Dufresn P., Goldstein R.S., Martin S.J. (2001), The Determinants of Credit Spread Changes, ,,The Journal of Finance”, vol. 56, nr 6, https://doi.org/10.1111/00221082.00402. 
Daniels K.N., Jensen M.S. (2005), The Effect of Credit Ratings on Credit Default Swap Spreads and Credit Spreads, ,The Journal of Fixed Income”, vol. 15, nr 3, https://doi. org/10.3905/jfi.2005.605421.

Delianedis G., Geske R. (1998), Credit Risk and Risk Neutral Default Probabilities: Information about Ratings Migrations and Defaults, Anderson School, UCLA, Los Angeles.

De Santis R.A. (2012), The Euro Area Sovereign Debt Crisis, Safe Haven, Credit Rating Agencies and the Spread of the Fever from Greece, Ireland and Portugal, European Central Bank Working Paper Series, nr 1419, European Central Bank, Frankfurt am Main.

Driessen J. (2005), Is Default Event Risk Priced in Corporate Bonds?, „The Review of Financial Studies", vol. 18, nr 1, https://doi.org/10.1093/rfs/hhi009.

Ederington L.H., Yawitz J.B., Roberts B.E. (1987), The Informational Content of Bond Ratings, „The Journal of Financial Research”, vol. 10, nr 3, https://doi.org/ 10.1111/j.1475-6803.1987.tb00492.x.

Elton E.J., Gruber M.J., Agrawal D., Mann C. (2001), Explaining the Rate Spread on Corporate Bonds, „The Journal of Finance”, vol. 56, nr 1, https://doi.org/10.1111/00221082.00324.

Fama E.F. (1970), Efficient Capital Markets: A Review of Theory and Empirical Work, „The Journal of Finance”, vol. 25, nr 2, https://doi.org/10.1111/j.1540-6261.1970. tb00518.x.

Geske R.L., Delianedis G. (2001), The Components of Corporate Credit Spreads: Default, Recovery, Taxes, Jumps, Liquidity and Market Factors, Anderson School, UCLA, Los Angeles.

Hite G., Warga A. (1997), The Effect of Bond-rating Changes on Bond Price Performance, „Financial Analysts Journal”, vol. 53, nr 3, https://doi.org/10.2469/faj.v53.n3.2083.

Holthausen R.W., Leftwich R.W. (1986), The Effect of Bond Rating Changes on Common Stock Prices, ,Journal of Financial Economics”, vol. 17, nr 1, https://doi.org/ 10.1016/0304-405X(86)90006-1.

Jewell J., Livingston M. (1999), A Comparison of Bond Ratings from Moody's, S\&P and Fitch IBCA, „Financial Markets, Institutions and Instruments”, vol. 8, nr 4, https://doi. org/10.1111/1468-0416.00029.

Jorion P., Zhang G. (2007), Information Effects of Bond Rating Changes: The Role of the Rating Prior to the Announcement, „The Journal of Fixed Income”, vol. 16, nr 4, https://doi.org/10.3905/jfi.2007.683317.

Kaminsky G., Schmuckler S.L. (2002), Emerging Market Instability: Do Sovereign Ratings Affect Country Risk and Stock Returns?, ,The World Bank Economic Review", vol. 16, nr 2, https://doi.org/10.1093/wber/16.2.171.

Kao C., Wu C. (1990), Two-step Estimation of Linear Models with Ordinal Unobserved Variables: The Case of Corporate Bonds, ,Journal of Business and Economic Statistics", vol. 8, nr 3, https://doi.org/10.1080/07350015.1990.10509802.

Katz S. (1974), The Price Adjustment Process of Bonds to Rating Reclassifications: A Test of Bond Market Efficiency, ,The Journal of Finance”, vol. 29, nr 2, https://doi. org/10.1111/j.1540-6261.1974.tb03069.x.

Kliger D., Sarig O. (2000), The Information Value of Bond Ratings, „The Journal of Finance", vol. 55, nr 6, https://doi.org/10.1111/0022-1082.00311.

Larrain G., Reisen H., von Maltzan J. (1997), Emerging Market Risk and Sovereign Credit Ratings, OECD Development Centre Technical Papers, nr 124, OECD, Paris. 
Liu P., Thakor A. (1984), Interest Yields, Credit Ratings and Economic Characteristics of State Bonds: An Empirical Analysis, „Journal of Money, Credit and Banking”, vol. 16, nr 3, https://doi.org/10.2307/1992222.

Löffler G. (2005), Avoiding the Rating Bounce: Why Rating Agencies Are Slow to React to New Information, ,Journal of Economic Behavior and Organization”, vol. 56, nr 3, https://doi.org/10.1016/j.jebo.2003.09.015.

Lugo S., Croce A., Faff R. (2013), Herding Behavior and Rating Convergence among Credit Rating Agencies: Evidence from the Subprime Crisis, https://papers.ssrn.com/ sol3/papers.cfm?abstract_id=2405411 (data dostępu: czerwiec 2018).

McKinnon R.I., Pill H. (1996), Credible Liberalizations and International Capital Flows: The Overborrowing Syndrome (w:) Financial Deregulation and Integration in East Asia, NBER-EASE, vol. 5, red. T. Ito, A.O. Krueger, University of Chicago Press, Chicago.

Norden L., Weber M. (2004), Informational Efficiency of Credit Default Swap and Stock Markets: The Impact of Credit Rating Announcements, ,Journal of Banking and Finance", vol. 28, nr 11, https://doi.org/10.1016/j.jbankfin.2004.06.011.

Partnoy F. (2001), The Paradox of Credit Ratings, University of San Diego Law and Economics Research Papers, nr 20, University of San Diego, San Diego.

Partnoy F. (2006), How and Why Credit Rating Agencies Are Not Like Other Gatekeepers, http://lamfin.arizona.edu/fixi/creditmod/Portnoy.pdf (data dostępu: czerwiec 2018).

Ramakrishnan R.T.S., Thakor A.V. (1984), Information Reliability and a Theory of Financial Intermediation, „Review of Economic Studies”, vol. 51, nr 3, https://doi. org/10.2307/2297431.

Reisen H., von Maltzan J. (1999), Boom and Bust and Sovereign Ratings, OECD Development Centre Working Papers, nr 148, OECD, Paris.

Scharfstein D.S., Stein J.C. (1990), Herd Behavior and Investment, „The American Economic Review", vol. 80, nr 3.

Skreta V., Veldkamp L. (2009), Ratings Shopping and Asset Complexity: A Theory of Ratings Inflation, NBER Working Paper, nr 14761, NBER, Cambridge.

Stiglitz J.E., Weiss A. (1981), Credit Rationing in Markets with Imperfect Information, „The American Economic Review”, vol. 71, nr 3.

West R.R. (1973), Bond Ratings, Bond Yield and Financial Regulation: Some Findings, „Journal of Law and Economics”, vol. 16, nr 1, https://doi.org/10.1086/466760.

Xia H. (2013), Can Investor-paid Credit Rating Agencies Improve the Information Quality of Issuer-paid Rating Agencies?, ,Journal of Financial Economics”, vol. 111, nr 2, https://doi.org/10.1016/j.jfineco.2013.10.015.

\section{Analysis of the Impact of Maintaining and Changing Credit Ratings on the Credit Spread on the Polish Corporate Bond Market in the Period 2010-2017}

(Abstract)

The purpose of the article is to determine the impact of maintaining and changing credit ratings formulated by the Moody's rating agency on the credit spread on the Polish debt market in the period 2010-2017. It seeks to draw conclusions on the efficiency of 
the Polish debt market with respect factors including raising, maintaining at the current level or lowering the rating. The methodology used in the paper is based on the standard procedure for studying events. The results of the conducted research are not unequivocal. While they indicate a correct response of the credit spread to changes in the credit ratings, the results obtained are not confirmed by statistical significance tests.

Keywords: credit spread, rating agencies, efficiency of debt market, Catalyst. 